\title{
NOTES ON THE INCIDENCE OF VENEREAL DISEASE IN THE BAHAMAS
}

\author{
BY
}

\author{
W. P. U. JACKSON
}

Formerly Medical Specialist R.A.F.V.R.

The Bahamas group of islands lie in the Caribbean Sea off the coast of Florida and are inhabited by some 60,000 people of whom the great majority are negroes of West African stock. At least one half of the native population live in a small area in the capital city, Nassau, in conditions of depressing squalor, filth, overcrowding, poverty, and ignorance. Nassau contains the Bahamas General Hospital-the only place in the island group at which pathological diagnostic and treatment facilities are available for venereal diseases. Incidentally, it may be recalled that Columbus first landed at San Salvador, an island of the Bahamas group, and there his crew may have acquired syphilis and later carried the disease back to the old world. The inhabitants in those days were Lucayan Indians.

The Bahamas are a lucky group of islands, for although they lie only just north of the Tropic of Cancer, they are spared most tropical diseases. Yaws does not appear, nor schistosomiasis, nor Leishmaniasis, nor trypanosomiasis. There is no malaria, despite the presence of Anopheline mosquitoes; no sandfly fever, despite myriads of sandflies; no yellow fever, although the Aedes, I understand, inhabits the island. Even ankylostomiasis does not exist because the soil is too porous to sustain the parasitic nematode (Beveridge, 1927). Leprosy is uncommon. The more temperate diseases, diphtheria and rheumatic fever, are not known. To make up for this, phthisis is a great scourge and tends to be exudative and rapidly progressive. Venereal diseases are almost the rule rather than the exception: syphilis, gonorrhœa, lymphogranuloma inguinale, and chancroid are all very common. Late syphilitic involvement of the central nervous system is very rare but that of the vascular system is common, and the local hospital even describes one or two cases per year of dissecting aneurism of the aorta due to syphilis.

\section{Civilian Native Population \\ (Chronic Syphilis)}

The performance of Kahn tests occupies a great deal of the working time of the pathological department at the Bahamas General Hospital. These examinations are made as a routine on all in-patients, on pregnant women who can be persuaded to attend hospital, on infants born in the maternity department, on volunteers for the police and serving forces, on "food-handlers," and on various other groups of people. The results of Kahn tests (Table I) include these routine examinations on persons in whom there was no reason to suspect the presence of venereal disease, and may therefore be considered as fair samples of the native community as a whole. Doubtful results are not included as positive unless definitely so on repetition. If doubtful reactions $( \pm$ ) were also included (a procedure claimed to be legitimate by Parran and others, 1941) the figures for positive tests would be about 20 per cent. higher.

TABLE I.

INCIDENCE OF POSITIVE KAHN REACTIONS AMONG THE NATIVE COMMUNITY

\begin{tabular}{l|c|c|c}
\hline \multirow{2}{*}{ Year } & \multirow{2}{*}{$\begin{array}{c}\text { Total } \\
\text { tested }\end{array}$} & \multicolumn{2}{|c}{ Positive } \\
\cline { 3 - 4 } & & Total & Per cent. \\
\hline 1939 & 5,489 & 1,453 & $26 \cdot 4$ \\
1940 & 5,037 & 1,360 & $27 \cdot 0$ \\
1941 & 5,163 & 1,075 & $20 \cdot 8$ \\
1942 & 5,342 & 1,035 & $19 \cdot 4$ \\
1943 & 4,760 & 826 & $17 \cdot 4$ \\
1944 & 4,881 & 928 & $19 \cdot 0$ \\
\hline
\end{tabular}


High though these figures are, the percentages of positive Wassermann reactions found among coloured draftees into the United States Army in the recent war were even greater in several states, e.g. 40.6 per cent. in Florida, with an average of $27 \cdot 2$ per cent. for all states (including doubtful reactions), (Vonderlehr and Usilton, 1942), while Keidel and Moore (1923) found an incidence of 22.9 per cent. of positive Wassermann reactors among negroes in 5,000 in-patients at Johns Hopkins Hospital. Incidentally these figures for positive syphilitic tests may be compared with those concerning the Frei test for lymphogranuloma inguinale in the United States. In two series, among United States negroes, positive results to the latter test were found in about 40 per cent. of cases (Gelperin, 1943 ; Beeson and Miller, 1944). It must, however, be remembered that the Frei test, once positive, remains so after the infection has cleared (Grace and Rake, 1943).

Some further details are available of the Kahn test results for the year 1943 in which, out of tests done on 414 pregnant women, 61 (14.7 per cent.) were positive. With regard to age, out of 200 consecutive people of both sexes between the ages of 18 and 22, 46 ( 23 per cent.) gave a positive result ; and in the age group 30 to 40 positive results were found in 60 (30 per cent.). In this year the male : female ratio of positive reactors was - very nearly $1: 1$. A point of interest here is the high rate of infection at the low age of 18 to 22 , and only a small increase in the infection rate among the 30 to 40 age group, the figures in both cases referring to the unselected general population. This contrasts with the negro rates in the United States, where $19 \cdot 1$ per cent. of Army draftees aged 21 to 25 drawn from all states had positive Wassermann reactions, while for the age group 31 to 35 the incidence had risen to 35.7 per cent. (Vonderlehr and Usilton, 1942). Incidentally the corresponding white rates were 1.0 per cent. and 3.7 per cent.-an even greater proportional difference.

Great difficulty was experienced in completing the treatment of syphilis in these coloured patients on account of their defaulting. Thus, at the Bahamas General Hospital, the average number of injections of an organic arsenical per patient was 6.3 and of bismuth 9.5. Smillie (1943) remarks that " among the whites syphilis has become, in the great

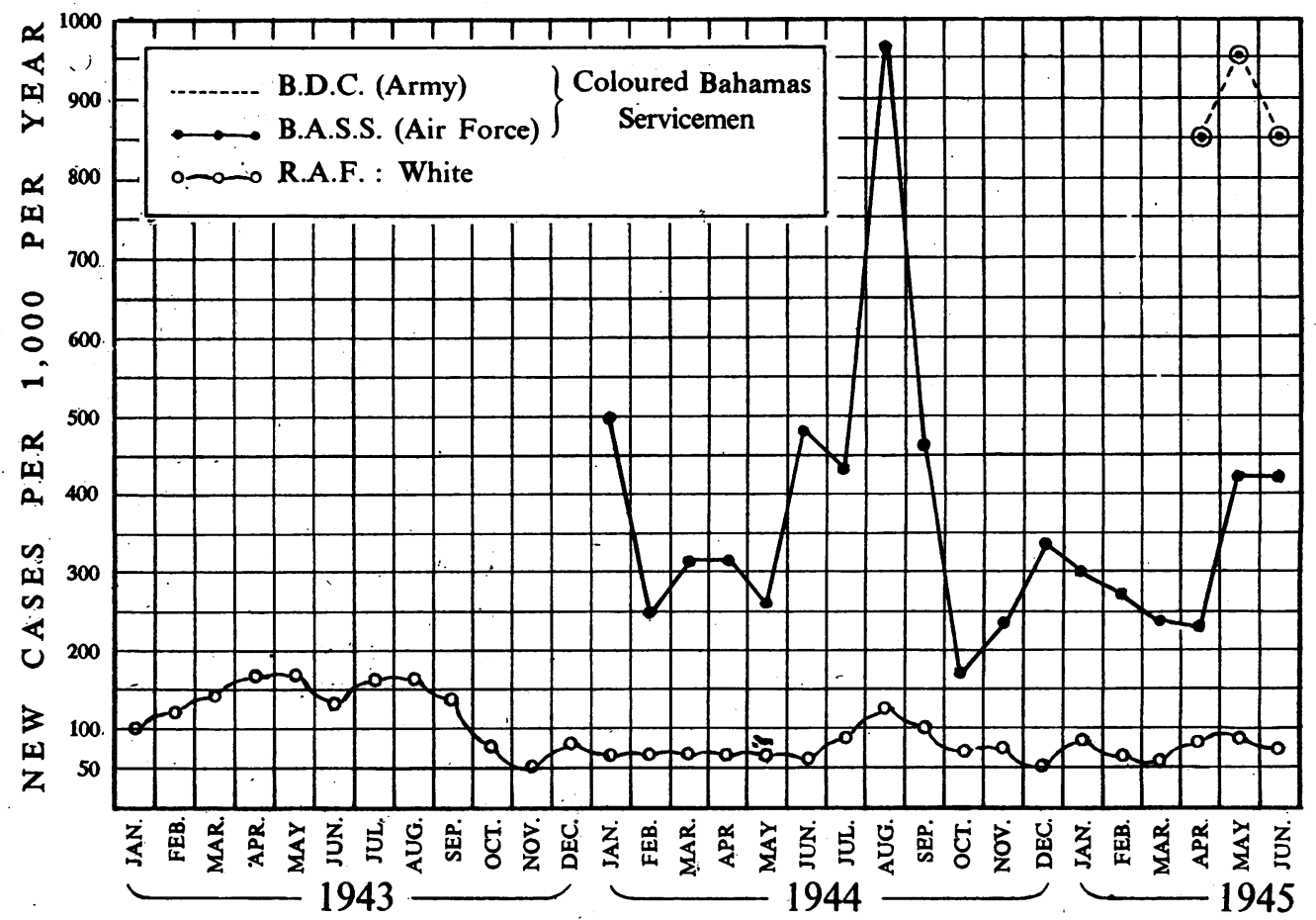


majority of cases, a disease of the ignorant, the careless, the criminal, and the social outcast," but it is evident, as Fullilove (1943) pointed out, that this applies to syphilis in any group of people, and to negroes as a whole, who are discriminated against economically and educationally. Following the advent of penicillin, which has shortened the course of treatment, a great reduction in the incidence of syphilis in the comparatively closed Bahamian community should result, but its eradication will have to await a very great raising of the living and educational standard of the coloured population.

\section{Royal Air Force}

In 1942 a large Royal Air Force unit was formed in the Bahamas and based on Nassau. It consisted of some 3,000 white troops and, from January, 1944, of a contingent of coloured men attached thereto, some 270 strong (Bahamas Air Service Squadron : "B.A.S.S."). In April, 1945, the R.A.F. Medical Service also started to look after the local coloured Army contingent of 360 men (the Bahamas Defence Corps : “B.D.C."). The prevalent venereal diseases were syphilis, gonorrhœa, lymphogranuloma inguinale, nongonococcal (or unproven) urethritis, balanitis, and soft sores. Many of the latter were examples of the chancroid caused by Ducrey's bacillus, which, until discovered in 1945 in the pathological department of the R.A.F. Hospital at Nassau, was not known to exist in the Bahamas. Because of this late discovery the exact number of true soft chancres in this series is not known.
The graph shows the monthly incidence of new cases of all types of venereal disease diagnosed in the white and the coloured contingents separately, the figures being reduced to show cases per 1,000 per annum. The high rate in August is interesting: it occurs in both white and coloured groups and shows an incidence in the coloured group (B.A.S.S.) of almost 1,000 per 1,000 per annum. August is the hottest and most humid month in the year in the Bahamas but contains no particular local festivities or orgies which might account for increased promiscuity. Gonorrhcea seemed to be the disease particularly affected in the peak but monthly figures for individual venereal diseases were too low to admit of any certain conclusions. Table II shows the relative frequency of the different venereal diseases, with a high proportion of syphilis among the white troops.

These rates compare unfavourably with those of the Allied troops in the Middle East, whose overall incidence of venereal disease in early 1943 was 30 per 1,000 per annum, or 18 per 1,000 considering British and Dominion troops only (Lees, 1946). The overall United States Army venereal disease rate in 1943 was 25.0 per 1,000 , having been 42.5 in 1940 (Turner, 1943), and that of the British Army 11 per 1,000 per annum between 1940 and 1943 (Grigg, 1943).

\section{Control and Treatment}

Attempts to reduce the incidence of venereal disease among white troops were made by lectures to the newly arrived men, by strict enforcement of the "out-of-bounds" limits which included the native quarter of the city,

TABLE II

RELATIVE FREQUENCY OF DIFFERENT VENEREAL DISEASES IN WHITE AND COLOURED TROOPS

\begin{tabular}{l|c|c|c|c|c|c}
\hline & \multicolumn{3}{|c|}{ Total Cases } & \multicolumn{3}{c}{ Ratio } \\
\cline { 2 - 6 } & Gonorrhoea & Syphilis & $\begin{array}{c}\text { Lympho- } \\
\text { granuloma } \\
\text { inguinale }\end{array}$ & Gonorrhœa & Syphilis & $\begin{array}{c}\text { Lympho- } \\
\text { granuloma } \\
\text { inguinale }\end{array}$ \\
\hline $\begin{array}{c}\text { White (3,000 men) ... } \\
\text { (Feb. 1943 to Jan. } \\
\text { 1945 incl.) }\end{array}$ & 197 & 91 & 53 & $2 \cdot 2:$ & $1:$ & 0.6 \\
$\begin{array}{c}\text { Coloured (270 men) .. } \\
\text { (Feb. 1944 to Jan. } \\
\text { 1945 incl.) }\end{array}$ & 53 & 10 & 16 & $5 \cdot 3:$ & $1:$ & 1.6 \\
\hline
\end{tabular}


and by the provision of " early treatment" rooms with the usual facilities supplied in the Services. Attempts were made to persuade the local authorities to enforce the law which penalized infected women who had further intercourse, and also to persuade such women to submit to treatment ; but without much success. These women were very difficult to trace because they could, and did, move their wooden homes on wheels overnight from one end of the native quarter to the other. Cooperation between the medical and the Provost Marshal's departments was considered very important, and there is no doubt that the excellent work of the latter department prevented much venereal infection.

The treatment of lymphogranuloma inguinale in men in the Royal Air Force in the Bahamas, especially from its surgical aspects, has been discussed by Maclaughlin (1945). The response to suphadiazine $(25$ to $30 \mathrm{~g}$. in five days) was found to be good. Only 13 cases out of 68 required two or more courses, 8 relapsed within six months, 4 required aspiration or more drastic surgical procedures, and 4 were moved from the Bahamas during the observation period.

Chancroid was found to respond even better to sulphadiazine in similar dosage, there being no chronic sequelæ or relapses. Satulsky (1945), and Combes and others (1943), with much larger numbers of patients, obtained similar good results using sulphathiazole.

Acute gonorrhcea on the whole responded well to sulphathiazole or sulphadiazine ; (Table III). Dosage was g. 8 - 6-6-6 on

\section{TABLE III}

RESULTS OF TREATMENT OF GONORRHCEA WITH SULPHATHIAZOLE OR SULPHADIAZINE

\begin{tabular}{|c|c|c|c|c|}
\hline \multirow[b]{3}{*}{$\begin{array}{l}\text { Total men } \\
\text { Cured by single course } \\
\text { Cured after two }\end{array}$} & \multicolumn{2}{|c|}{ White } & \multicolumn{2}{|c|}{ Coloured } \\
\hline & Total & $\begin{array}{l}\text { Per } \\
\text { cent. }\end{array}$ & Total & $\begin{array}{l}\text { Per } \\
\text { cent. }\end{array}$ \\
\hline & $\begin{array}{l}198 \\
156\end{array}$ & $\overline{78}$ & $\begin{array}{l}65 \\
48\end{array}$ & $\overline{72 \cdot 5}$ \\
\hline 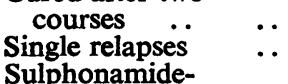 & $\begin{array}{r}175 \\
6\end{array}$ & $\begin{array}{r}88 \\
3\end{array}$ & $\begin{array}{r}61 \\
1\end{array}$ & $\begin{array}{c}94 \\
1.5\end{array}$ \\
\hline $\begin{array}{l}\text { resistant } \\
\text { Left the Bahamas } \\
\text { during observation }\end{array}$ & 17 & $8 \cdot 7$ & 3 & $4 \cdot 6$ \\
\hline period & 21 & - & 0 & - \\
\hline
\end{tabular}

successive days, and the patients were followed up for six months, except when they had left the Bahamas before this period ended. Thus, until mid 1945, when penicillin therapy was instituted initially as a routine, there had been no evidence of sulphonamide resistance in any gross degree. McElligott (1945) remarks that negroes with gonorrhoea respond more favourably to all forms of treatment than do white men, and certainly even here the percentage of resistant infections in white patients was almost double that in the coloured men, but the figures are too small to be significant.

\section{Conclusion}

These brief notes, with rather small figures, are intended partly as a record and partly to show that there is very considerable room for improvement in the venereal disease position in one of our colonies, which is incidentally a favourite winter resort.

I should like to thank Squadron-Leader B. Goodrich, who was in charge of the Venereal Disease department of the R.A.F. Hospital for part of the period referred to ; and also the Chief Medical Officer of the Bahamas for permission to use the data obtained from the Bahamas General Hospital.

\section{REFERENCES}

Beeson, P., and Miller, E. S. (1944). Amer. J. Publ. Hith., 34, 1076.

Beveridge, Sir W. (1927). Report on Public Health and Medical Conditions in New Providence.

Combes, F. C., Canizares, O., and Landy, S. (1943). Amer. J. Syph., 27, 700.

Fullilove, R. E. (1943). J. Amer. med. Ass., 122, 764.

Grace, A. W., and Rake, G. (1943). Arch. Derm. Syph., Chicago, 48, 619.

Gelperin, A. (1943). Amer. J. Syph., 27, 697. Grigg, James (1940-3). Parliamentary Reports, London.

Keidel, A., and Moore, J. E. (1923). Johns Hopk. Hosp. Bull., 34, 16.

Lees, R. (1946). Brit. J. vener. Dis., 4, 150.

Maclaughlin, C. R. (1945). Lancet, 1, 807.

McElligott, G. L. M. (1945). Bull. War Med., 5, 771.

Parran, T., Hazen, H. H., Mahoney, J. F., Sanford, A. H., Senear, F. E., Simpson, W. M., and Vonderlehr, R. A. (1941). J. Amer. med. Ass., 117, 1167.

Satulsky, E. M. (1945). Ibid., 127, 259.

Smillie, W. G. (1943). Ibid., 122, 365.

Turner, T. B. (1943). Amer. J. Publ. Hlth., 33, 1309.

Vonderlehr, R. A., and Usilton, L. J. (1942). Ibid., 120, 1369. 